\title{
Prosperidade sim, família homossexual, não! A nova classe média evangélica
}

\author{
Jung Mo Sung* \\ Universidade Metodista de São Paulo, Programa de Pós-Graduação em Ciências da Religião. São Paulo, SP, Brasil
}

Resumo: Dentre a chamada "nova classe média", um grupo social se destaca por sua atuação social e política em defesa do modelo tradicional de família e contra o casamento de pessoas do mesmo sexo e as relações homoafetivas: os evangélicos da linha da teologia da prosperidade. Este artigo pretende mostrar que o conservadorismo moral militante e a adesão aos valores modernos e pós-modernos da cultura de consumo capitalista, por meio da teologia da prosperidade, não são aspectos contraditórios ou um descompasso no processo de modernização desse grupo, mas que são dois lados de um único processo de afirmação de sua dignidade humana.

Palavras-chave: evangélicos, teologia da prosperidade, família, homofobia, religião, modernidade.

A eleição, em 2013, do Deputado Marco Feliciano para a presidência da Comissão dos Direitos Humanos e Minorias da Câmara Federal foi objeto de muita polêmica no Brasil. Para os críticos dessa eleição, a questão fundamental foi: "Como pode um pastor evangélico pentecostal acusado de ser homofóbico e racista presidir essa Comissão?" O pastor deputado se defendeu da acusação de racismo - afirmando que a sua mãe era negra -, mas não da de homofobia, pois ele se apresenta como defensor da família no sentido tradicional, isto é, da família heterossexual.

O caso específico da eleição de Feliciano para a presidência dessa comissão pode ter sido resultado de um descaso dos principais partidos em relação ao tema dos direitos humanos, mas mostrou à sociedade o peso e a articulação da "bancada evangélica" e a força política e social de uma parcela da população brasileira que é, muitas vezes, objeto de preconceito por setores que se consideram modernos e ilustrados: os evangélicos que assumem a teologia da prosperidade e defendem, ao mesmo tempo, valores familiares e sexuais tradicionais.

A força social e eleitoral desse grupo foi sentida também, por exemplo, na eleição presidencial de 2010, quando parcelas importantes do mundo evangélico se uniram contra a candidatura da atual presidente Dilma Rousseff por causa do possível apoio dela ao casamento homossexual sob a forma de união civil de pessoas do mesmo sexo.

A defesa do modelo tradicional da família pelas igrejas cristãs não é novidade. A Igreja Católica, por exemplo, sempre teve uma postura de desconfiança em relação ao mundo moderno, não somente em termos de família e sexualidade, mas também em relação à cultura de consumo, o que também é verdade para setores evangélicos mais tradicionais, que continuam se opondo à cultura moderna como um todo. No caso dos evangélicos, a novidade que

\footnotetext{
* Autor correspondente: jungmosung@uol.com.br
}

pastores e lideranças como Feliciano e outros representam é a junção que fazem de dois valores aparentemente contraditórios: a adesão à cultura do consumo do capitalismo globalizado através da teologia da prosperidade; e, ao mesmo tempo, serem radical e militantemente contra novos comportamentos e valores sexuais e familiares dessa mesma sociedade em que estão ascendendo como parte da "nova classe média".

Mais do que abraçar dois valores vistos como conflitantes, um provindo do mundo pré-moderno e outro do moderno, o que mais chama a atenção é o modo militante $\mathrm{e}$ até agressivo com que esses setores da sociedade se opõem a formas alternativas de conceber a família e a sexualidade. Entre os católicos e protestantes de igrejas históricas (como luteranos e anglicanos), não é tão difícil encontrar pessoas que não concordam com a união civil de pessoas do mesmo sexo - um católico tradicional não chamaria essa união de família -, mas essas pessoas não assumem uma postura militante contra e podem respeitar quem defende e/ou vive essa forma de relacionamento afetivo-sexual.

À primeira vista, a forma agressiva com que esses evangélicos lidam com a questão da família não tradicional pode ser entendida como um certo descompasso no processo de modernização desse setor da sociedade. Isto é, se trataria de um setor da "nova classe média" que está ascendendo no padrão de consumo, teria abraçado um aspecto da vida moderna - a cultura do consumo -, mas ainda não teria tido tempo ou educação suficiente para aceitar, do mundo moderno, a pluralidade de modelos de família e de vida sexual. Eles estariam com um pé no mundo moderno e outro ainda no mundo tradicional, faltandolhes dar mais alguns passos em direção à modernidade $\mathrm{e}$ pós-modernidade.

No entanto, esse tipo de compreensão linear dos processos culturais não nos parece suficiente para compreender a agressividade antes mencionada, bem como a relação entre a teologia da prosperidade - a compreensão 
de que uma das formas concretas de bênçãos divinas se manifestarem na vida de um crente é a sua prosperidade econômica e o consequente aumento de seu padrão de consumo - e essa agressividade militante no campo sexual e familiar.

Por isso, o objetivo central deste artigo é propor algumas reflexões sobre essa relação entre a teologia da prosperidade e o "conservadorismo" moral familiar que caracteriza uma parcela significativa da "nova classe média" brasileira. A hipótese é que essa militância e agressividade estão determinadas pela teologia da prosperidade, isto é, essa teologia que articula fé com prosperidade econômico-financeira leva quase que necessariamente à postura contra o casamento de pessoas de mesmo sexo e o homossexualismo.

\section{Teologia da prosperidade, teologia da libertação e a modernidade}

Antes de entrarmos na discussão sobre a relação entre teologia da prosperidade e conservadorismo moral, penso que é importante fazermos uma breve reflexão sobre o que está subjacente na expressão "teologia da prosperidade": a relação entre fé/religião e economia.

Para pessoas que pensam dentro e a partir da cultura moderna, não há sentido em relacionar a fé/teologia com questões econômicas porque a religião deve ou deveria tratar somente das questões do campo privado e da salvação eterna. Em outras palavras, o mundo deveria ser dividido em duas esferas: a secular, que muitos identificam com a esfera pública, e que seria objeto de estudo e intervenção das ciências e da política; e a religiosa, que deveria ser restrita à esfera do privado e das preocupações com a vida pós-morte.

Dentro dessa concepção de religião, Deus, fé e teologia não têm ou não deveriam ter nada a ver com questões econômicas, políticas e sociais. Por ocasião do surgimento da teologia da libertação (no final dos anos 1960 e início dos 70), essa questão foi objeto de muito debate no interior das igrejas cristãs e na sociedade. Eu me lembro de uma entrevista do então Presidente da República Fernando H. Cardoso diante de uma crítica dos bispos católicos sobre uma questão política. Ele respondeu como responderia um típico cientista social moderno: os bispos devem se ocupar das questões religiosas, e não de questões políticas, que são da esfera pública e secular.

Penso que sobre a teologia da prosperidade há um preconceito ou incompreensão maior do que em relação à teologia da libertação. No caso dessa última, muitos pensadores críticos do capitalismo a apoiaram por causa de seu caráter anticapitalista e de sua luta em favor da justiça social, além de seu diálogo com ciências sociais modernas, especialmente de corte dialético-marxista. No caso da teologia da prosperidade, as coisas são bem diferentes porque seus "teólogos" ou divulgadores mais conhecidos não costumam ter títulos acadêmicos de universidades reconhecidas (é preciso lembrar que a primeira geração de teólogos da libertação obteve seus doutorados em grandes universidades europeias e norte-americanas) e, o mais grave, não dialogam com as ciências modernas, mas se fundamentam basicamente em citações bíblicas.

Contudo, é preciso reconhecer que há dois pontos em comum nessas duas teologias. As duas não aceitam a ideia de que Deus é indiferente ao sofrimento corporal do seu povo ou, pior, que a pobreza dos pobres é da vontade de Deus. Isto é, não aceitam uma visão pessimista do ser humano como ser decaído que merece sofrer, e uma noção quase sádica de Deus, que exigiria dos seus filhos "amados" sofrimento na terra para dar em troca a vida eterna. Permita-me fazer uma citação sem citar por ora o seu autor:

$\mathrm{Eu}$ jamais concordei com alguns "doutores" de Teologia que ensinam que o ser humano não vale coisa alguma. Dizem alguns que não passamos de simples vermes a rastejar sobre o pó da terra. Para mim isso, além de absurdo, é mentira.

Todos creem, inclusive esses "doutores", no fato de Jesus ter pagado um alto preço para nos resgatar -0 que é verdade. Mas, se o preço pago foi alto, é porque temos um alto valor para Deus. Não há quem pague muito por algo desprezível; pelo contrário, para o que vale muito, não se medem esforços. Isso foi o que o Senhor Jesus fez ao morrer por nós no Calvário. E, se o preço pago foi alto, é porque o nosso valor também é.

Se você deseja ser um vencedor sobre a doença, a miséria, o pecado e todo o poder do diabo, continue comigo, lendo este livro.

O texto é dirigido ao público cristão em geral, numa linguagem tipicamente religiosa cristã, e critica a visão antropológica pessimista presente no cristianismo. Após revalorizar o ser humano através de uma teologia da cruz bem tradicional, familiar aos seus leitores, o autor os convoca a lutar para vencer os males da vida: a doença e a miséria, que são atribuídas ao poder do diabo. Com essa atribuição, o autor está afirmando que essa situação é contrária à vontade de Deus. Esse é um texto que poderia ter sido escrito por um padre ou um teólogo da libertação. Mas, na verdade foi escrito por um dos principais representantes da teologia da prosperidade, R. R. Soares (2009, p. 10), fundador da Igreja Internacional da Graça.

É claro que um trecho isolado do seu contexto mais amplo pode transmitir uma compreensão equivocada da tese do autor. Mas, não se pode negar no trecho a convergência com a noção da teologia da libertação de que Deus está ao lado dos pobres na luta para superar a condição de pobreza.

$\mathrm{Eu}$, como teólogo da libertação, além de pesquisador na área das ciências da religião, não estou nem de longe querendo dizer que não há diferenças fundamentais entre essas duas teologias. Com certeza, uma diferença 
fundamental está na compreensão das causas da pobreza e nos objetivos sociais e religiosos a serem alcançados com luta. Mas, não podemos perder de vista que essas duas teologias estão do mesmo lado na oposição a teologias que apresentam um Deus indiferente aos problemas sociais e/ou apresentam o sofrimento da pobreza e enfermidade como o caminho ou o preço da salvação.

Isso nos leva ao segundo ponto em comum entre essas duas teologias: a não aceitação da redução da religião à esfera da vida privada e da salvação eterna pós-morte. Para compreendermos melhor essa questão, é preciso ter em mente que a religião reduzida à esfera do privado e entendida como oposta ao secular, à esfera da vida pública, é uma invenção da Europa Ocidental moderna para solucionar problemas advindos das guerras de religiões e do processo de modernização com o advento do capitalismo (Asad, 1993, 2003; Masuzawa, 2012; Nongbri, 2013)

Por mais surpreendente que possa parecer aos modernos, diversos estudos nos mostram que nas sociedades antigas não havia um conceito de religião. Isso fica mais claro se levarmos em consideração que para que se possa definir o "ser religioso" é preciso que haja a noção de um ser não religioso, e essa dicotomia não existia no mundo antigo. Como diz Nongbri (2013),

está se tornando claro que a separação de algo chamado "religião" como uma esfera da vida idealmente separada da política, economia e ciências não é uma característica universal da história humana. . . No mundo antigo, os deuses estavam envolvidos com todos os aspectos da vida. (pp. 2-3)

Mais do que simples envolvimento, as religiões forneciam os princípios organizadores da vida social, das relações interpessoais, da cosmovisão, e eram fundamento da ordem social-natural. Por isso, religião não era nomeada como algo separado de outras esferas ou campos.

O que ocorreu no Japão no século XIX nos serve como um exemplo do que estamos tratando. Jason Ananda Josephson (2012), no seu livro The Invention of Religion in Japan, mostra que não havia no Japão uma palavra que correspondesse ao que hoje nomeamos como religião. Isso se tornou um problema quando os norte-americanos forçaram o governo japonês a assinarem um tratado, em 1853, que incluía uma cláusula de liberdade religiosa no país. Como a língua japonesa não tinha uma palavra correspondente para religião, o tradutor teve que criar um neologismo, Shukyo, que literalmente significa "ensinamento de uma seita".

Não é nosso objetivo aqui aprofundar a questão da criação de uma nova palavra para dar conta do que o mundo moderno ocidental chamou de religião, e da diferença do sentido moderno da palavra religião em relação ao religio (latim) e a threskeia, palavra grega encontrada no Novo Testamento que é usualmente traduzida como "religião". $\mathrm{O}$ que nos interessa aqui é compreender melhor o segundo ponto em comum entre a teologia da prosperidade e a teologia da libertação. Elas se opõem à redução da religião ao campo do que os modernos chamam de "religioso", ao privado e às questões do "divino", como fazem, por exemplo, diversos teólogos liberais. Na medida em que a referência primária dessas duas teologias é a Bíblia, um conjunto de livros considerados sagrados e escritos no mundo tradicional pré-moderno, elas não aceitam que questões econômicas, sociais e políticas estejam fora do alcance de sua missão religiosa. Todos os aspectos da vida social têm a ver com Deus e a fé religiosa. É por isso que diversos autores da teologia da libertação escreveram obras de crítica teológica à economia (por exemplo Assmann \& Hinkelammert, 1989; Assmann, 1994; Sung, 1994), assim como a teologia da prosperidade relaciona a fé com a prosperidade econômica.

\section{Capitalismo como religião e seus demônios}

Se no passado a religião exercia a função de dar coesão e ordem à sociedade, oferecendo os critérios últimos para a legitimação, organização e classificação das instituições e relações humanas e sociais, e hoje ela foi reduzida à esfera do privado, a pergunta que surge é: o que a substituiu nessa função?

A pergunta sobre os fundamentos e pressupostos do mundo moderno que o diferenciam do mundo pré-moderno transcende em muito o objetivo deste artigo, mas é preciso tê-la em conta, pois estamos estudando um grupo religioso que compreende a sua vida na sociedade capitalista atual a partir de alguns princípios pré-modernos. Por isto, penso que é útil para o nosso objetivo fazer uma breve reflexão sobre a tese de Walter Benjamin de que o capitalismo é, no fundo, uma religião.

Benjamin, no seu fragmento "Capitalismo como religião" (1985/2013), diz:

O capitalismo deve ser visto como uma religião, isto é, o capitalismo está essencialmente a serviço da resolução das mesmas preocupações, aflições e inquietações a que outrora as assim chamadas religiões quiseram oferecer resposta. A demonstração da estrutura religiosa do capitalismo, que não é só uma formação condicionada pela religião, como pensou Weber, mas um fenômeno essencialmente religioso, nos levaria ainda hoje a desviar para uma polêmica generalizada e desmedida. (p. 21)

Nessa afirmação, podemos encontrar pelo menos três teses bastante provocativas. A primeira, e com certeza a central, é a afirmação de que o capitalismo não é um sistema social secularizado, mas é ou funciona como uma religião. Ela rompe com a visão tradicional do mundo moderno e do capitalismo como secularizados, que teriam se emancipado do mundo dominado pela religião. Essa tese implica também em repensar o próprio conceito moderno de religião - questão que abordamos acima. 
A segunda tese aparece na justificativa dada por Benjamin para ver no capitalismo uma religião. Ele diz que "o capitalismo está essencialmente a serviço da resolução das mesmas preocupações, aflições e inquietações a que outrora as assim chamadas religiões quiseram oferecer resposta." Nessa afirmação podemos ver dois tipos de religiões: (a) as religiões de hoje, que não respondem mais ou que têm suas respostas não mais aceitas para questões que (b) as religiões do passado costumavam resolver. Isto é, no passado, as religiões resolviam as grandes questões da vida social - na verdade, a totalidade das questões sociais e políticas -; e as modernas não conseguem mais cumprir essa função, por conta da distinção entre a religião e o secular. A função realizada no passado pelas religiões não é realizada pelo "secular", oposto ao religioso, mas pelo próprio sistema capitalista.

A terceira tese presente na citação do texto de Benjamin é a de que a teoria weberiana do papel da religião, em particular do cristianismo calvinista, na formação do espírito do capitalismo não é suficiente para compreender a gênese e a estrutura do capitalismo. Mais do que condicionado pela religião, para Benjamin, o capitalismo tem uma estrutura religiosa. Ele próprio reconhece que está adentrado uma discussão que geraria muita polêmica. Não somente no tempo dele, mas ainda hoje, se levarmos em consideração o peso que a teoria de Max Weber tem no estudo da religião e do desencantamento do mundo moderno.

Mesmo sem aprofundar aqui a discussão, quero citar um texto de Weber que nos oferece uma pista realmente interessante para a ideia do capitalismo como religião. Ao analisar a "ciência como uma vocação" e "as lutas de deuses" que ocorrem nas sociedades, Weber (1917/2001) diz:

Desconheço como se poderia encontrar fundamento para decidir "cientificamente" a questão do valor da cultura francesa comparada à alemã. Também ai diferentes deuses se combatem e, por certo, infinitamente. Por conseguinte, tudo se passa exatamente como se passava no mundo antigo, que se encontrava sob o encanto dos deuses e demônios, conquanto assuma diferente sentido. Ofereciam sacrifícios a Afrodite os gregos, depois a Apolo e, acima de tudo, a cada um dos deuses da cidade. Continuamos a proceder de maneira semelhante, conquanto nosso comportamento haja rompido o encanto e se haja despojado do mito que ainda vive em nós. (pp. 48-49)

Para Weber não há grande diferença entre o mundo antigo e o moderno: continuamos oferecendo sacrifício aos deuses. Só que agora isto assume um sentido diferente. Antes era para deuses pessoais, porque o mundo era encantado; hoje, em um mundo desencantado, os sacrifícios são oferecidos a forças impessoais, às leis do sistema de mercado. Por isso, ele diz: "Atualmente, a religião tornouse 'rotina do dia-a-dia'. Os deuses antigos abandonaram suas tumbas e, sob a forma de poderes impessoais, porque desencantados, esforçam-se por ganhar poder sobre nossas vidas, reiniciando suas lutas eternas." (p. 49).

Quero dar um pequeno exemplo visando tornar mais claro como esse "capitalismo como religião" está presente no nosso cotidiano. No passado, quando uma pessoa se sentia com baixa autoestima, deprimida, impura ou pecadora, ela ia a um templo, lugar sagrado, para recuperar a sua pureza e força para viver. O contato com o sagrado lhe purificava e dava forças porque, na cosmovisão religiosa, o Sagrado é a fonte de pureza e da força vital. Na nossa sociedade capitalista, com a cultura de consumo, uma pessoa em semelhante situação de "mal-estar" vai a um Shopping Center fazer compras ou simplesmente contemplar vitrines. ${ }^{2}$ Não é por acaso que muitos dos Shoppings possuem características arquitetônicas que nos lembram catedrais ou outros tipos de templos religiosos.

$\mathrm{Na}$ medida em que as religiões vão perdendo a capacidade de fornecer à sociedade os critérios últimos para discernir a vida pessoal e as relações sociais, o sistema capitalista vai tomando o seu lugar. Na evolução do capitalismo no Ocidente, precisamos diferenciar a época da ética do trabalho - analisada por Weber - da cultura de consumo capitalista, que vai tomando lugar, especialmente a partir do fim da Segunda Guerra Mundial no Primeiro Mundo, e, no caso do Brasil, após o milagre econômico do final dos anos 1960 e início dos anos 70 . O padrão de consumo passa a ocupar um lugar central nos processos de ordenação e classificação das relações sociais.

Neste contexto, Bauman (1998) nos alerta que:

Se o consumo é a medida de uma vida bem-sucedida, da felicidade e mesmo da decência humana, então foi retirada a tampa dos desejos humanos: nenhuma quantidade de aquisições e sensações emocionantes tem qualquer probabilidade de trazer satisfação da maneira como o "manter-se ao nível dos padrões" outrora prometeu: não há padrões a cujo nível se manter - a linha de chegada avança junto com o corredor, e as metas permanecem continuamente distantes, enquanto se tenta alcançá-las. (p. 56)

A insatisfação permanente e o dever de sempre continuar correndo em busca de metas que sempre estão se afastando para mais longe produzem nas pessoas dessa sociedade uma ansiedade e insegurança quase insuportáveis e geram uma instabilidade perigosa para o sistema social. Por isso, como em todas as outras ordens sociais, é necessário projetar a ambivalência e instabilidade interna para o exterior e desenvolver uma mentalidade de fortaleza sitiada. Esses inimigos nada mais são do que as imagens espelhadas da sociedade que as gera, só que com sinal negativo.

Os inimigos que lhe sitiaram os muros são os seus próprios "demônios interiores" - os medos

2 Sobre esse assunto vide, por exemplo, Padilha (2006). 
reprimidos e circundantes que lhe permeiam a vida diária e a "normalidade", e que, no entanto, a fim de se tornar suportável a realidade diária, devem ser dominados, extraídos do cotidiano vivido e moldados em um corpo estranho, um inimigo tangível com que se possa lutar, e lutar novamente, e lutar até sob a esperança de viver. (Bauman, 1998, pp. 52-53)

E quem são esses inimigos da sociedade que precisa lidar com a ansiedade e a insegurança nascidas da busca do consumo infinito? São exatamente os "consumidores falhos", os excluídos do jogo e da sociedade, os que encarnam os demônios interiores da cultura de consumo. Por isso, "cada vez mais, ser pobre é encarado como um crime; empobrecer, como produto de predisposições ou intenções criminosas - abusos de álcool, jogos de azar, drogas, vadiagem e vagabundagem. Os pobres, longe de fazer jus a cuidado e assistência, merecem ódio e condenação - como a própria encarnação do pecado.” (Bauman, 1998, p.59)

\section{Teologia da prosperidade e a afirmação da dignidade dos pobres crentes}

É dentro desse contexto mais amplo que precisamos compreender o surgimento e a expansão acelerada da teologia da prosperidade no Brasil. Diferentemente dos protestantes bem integrados na sociedade capitalista e com acesso ao pensamento moderno ilustrado, os evangélicos pobres não possuem ou têm poucos "instrumentos" culturais não religiosos para se defenderem dessa "acusação" de serem pobres, para afirmarem a sua dignidade humana.

A Igreja Universal do Reino de Deus, uma das principais divulgadoras da teologia da prosperidade, foi criada em 1977 na cidade do Rio de Janeiro. O lugar e a data não são uma mera coincidência. $O$ Brasil vivia o seu tempo pós-milagre econômico e a difusão da cultura de consumo pela TV; o Rio de Janeiro era (e continua sendo) uma cidade caracterizada por uma divisão bastante visível entre o setor rico, que vive o consumo de luxo então divulgado pelo padrão Globo de TV, e um setor marginalizado começando a internalizar a cultura de consumo e sua acusação silenciosa contra os pobres.

Em um contexto social assim, aos pobres lhes resta o caminho de: a) aceitar passivamente a exclusão e a acusação - o que não é possível por muito tempo sem uma reação violenta contra si e/ou a sociedade; b) ascetismo protestante, que era divulgado pelas igrejas de corte calvinista e pentecostais mais tradicionais, que lhes garantiria o senso de dignidade diante de Deus em total oposição ao "mundo" - caminho difícil de sustentar pela força da mídia na difusão da cultura de consumo; c) engajamento na luta pela superação do sistema capitalista que marginaliza os pobres, em busca de uma sociedade alternativa sem exclusão - o caminho das CEBS e da teologia da libertação; d) teologia da prosperidade, que afirma a dignidade de todas as pessoas que aceitam Jesus e que, por isso, recebem do "poder de Deus" a benção na forma de prosperidade e saúde.

A grande diferença entre a teologia da libertação e a teologia da prosperidade está no fato de que a primeira afirma a dignidade humana de todas as pessoas, isto é, a dignidade universal independente da confissão religiosa e da pobreza, em oposição ao sistema capitalista, enquanto a segunda pretende defender a dignidade e a "inocência" dos pobres crentes frente à acusação da sociedade, através da inclusão deles no consumo, sem questionar os critérios da cultura de consumo capitalista. Isto é, a primeira busca a superação do sistema capitalista; a segunda, a integração e ascensão no interior da classificação social capitalista.

O caminho das CEBS/TL pressupõe conhecer os mecanismos invisíveis do sistema capitalista e depois o engajamento na luta social e política para a superação do capitalismo e a construção do "Reino de Deus". Neste sentido, as CEBS são pré-modernas no juízo religioso contra o capitalismo, e bastante modernas na afirmação da ação humana na construção de uma sociedade justa e igualitária, na construção do Reino de Deus. Enquanto as igrejas que assumem a teologia da prosperidade são modernas na aceitação da cultura de consumo; e pré-modernas na crença de que é através das bênçãos e do poder de Deus que conseguirão a prosperidade.

Por mais críticas que possamos fazer à teologia da prosperidade, especialmente aos líderes que, em coerência com sua teologia, acumulam riquezas em nome da sua fé e do seu poder espiritual, é preciso reconhecer que essa teologia trouxe aos pobres dois pontos que penso serem positivos. O primeiro é a afirmação da dignidade humana dos pobres contra o pessimismo cristão e a acusação silenciosa da cultura de consumo. Como vimos na citação de R. R. Soares, eles foram comprados pelo sangue de Jesus porque têm muito valor! O segundo é: a pobreza e a vida ascética não voluntária que decorre dela não são da vontade de Deus; todos têm direito a uma vida com dignidade, alegria e prazer de viver.

A fé no poder de Deus dá a esses cristãos uma conviç̧ão pessoal, autoconfiança e determinação que lhes permitem inserir-se no mercado cada vez mais competitivo; e, o mais importante, ter uma vida pessoal e comunitária de melhor qualidade. Podemos dizer que, se a ética protestante ascética possibilitou a inserção dos camponeses no mundo industrial e alavancou o crescimento do capitalismo industrial, a teologia da prosperidade ajuda pobres de culturas pré-modernas a competirem no mercado de trabalho pós-fordista e entrarem na cultura de consumo pós-moderna. Em certo sentido, ela ajuda na luta pela diminuição da miséria e pobreza no país.

Não é difícil assim compreender por que o caminho da teologia da prosperidade, que exige muito menos energia do que o das CEBS por não ter que se opor aos valores fundamentais da cultura onde se está inserido, teve maior aceitação dos setores pobres da sociedade, incluindo aqui os pentecostais tradicionais (de moral mais ascética, com 
igrejas fundadas antes da teologia da prosperidade), que aos poucos foram assimilando essa teologia. ${ }^{3}$

Porém, o caminho não é tão simples e linear.

\section{A identidade dos evangélicos da prosperidade e a homofobia}

Ao falarmos do caminho escolhido pelas comunidades evangélicas da teologia da prosperidade ${ }^{4}$ para a integração no mercado de consumo, não podemos esquecer que, ao mesmo tempo em que desejam se integrar, sua identidade está profundamente marcada por "não serem do mundo", por estarem em oposição ao "mundo" entendido como lugar de pecado e de tentações que levam à perdição.

Como desejar entrar no "mundo" e participar das bênçãos que permitem consumir bens que a sociedade propaga como caminhos de felicidade sem, ao mesmo tempo, perderem a identidade de não serem do mundo? Aqui, me parece, encontramos a base da articulação entre a teologia da prosperidade e a agressividade contra o homossexualismo e o casamento de pessoas do mesmo sexo.

A diferenciação com o "mundo" se dá no campo da moral sexual e familiar. Os evangélicos pentecostais tradicionais anteriores à teologia da prosperidade se opunham ao "mundo" pela vida ascética, tanto no campo econômico do consumo de mercadorias quanto no familiar e sexual. Essa é a razão, por exemplo, da modéstia no vestir. Modéstia essa que representava oposição ao luxo e às tentações sexuais. Vale relembrar que nessa época, antes da disseminação da cultura de consumo, não se condenava os pobres por sua pobreza. Era o tempo em que as pessoas pobres tinham orgulho próprio porque eram trabalhadoras e tinham uma vida moral e religiosa reta ("pobre, mas trabalhador honesto!").

Com a cultura de consumo e a teologia da prosperidade, a modéstia no vestir dos evangélicos foi se modificando. Manteve-se a modéstia contra a sensualidade exacerbada, mas aprovam-se roupas que mostram como a pessoa é abençoada por Deus, isto é, roupas caras.

Mas a simples manutenção da moral conservadora não explica, por si, o tom militante e até agressivo contra o homossexualismo e o casamento ou união civil de pessoas do mesmo sexo. Nossa hipótese é de que essa militância está ligada à própria teologia da prosperidade - ao modo como se explica a passagem da pobreza para a prosperidade. Na cultura capitalista moderna, a ascensão social ou a prosperidade das pessoas são explicadas por razões econômicas e profissionais. Em geral, a explicação básica é a eficiência e trabalho duro em um ambiente profissional ou

3 Juan Luis Segundo, um dos principais nomes da primeira geração de teólogos da libertação, escreveu em 1973, no seu livro Massas e minorias na dialética divina da libertação, que esse tipo de cristianismo que luta por valores universais contra todas as absolutizações no mundo que excluem, exige muita energia dos seus militantes e, portanto, não é para as massas.

4 Essa adjetivação é necessária porque existem muitas comunidades evangélicas, pentecostais ou não, que estão distantes da teologia da prosperidade. econômico favorável. Porém, essa explicação não é apropriada ou suficiente para pobres ou pessoas de classe média baixa em dificuldades econômicas. Se fosse, não haveria necessidade da adesão à teologia da prosperidade.

Kenneth Hagin (n.d.), um dos principais divulgadores da teologia da prosperidade nos seus inícios nos Estados Unidos, disse: "Nós, como cristãos, não precisamos sofrer revezes financeiros; não precisamos ser cativos da pobreza ou da enfermidade! Deus proverá a cura e a prosperidade para seus filhos se eles obedecerem aos seus mandamentos. . . Deus quer que seus filhos. .. tenham o melhor de tudo" (p. 66). A chave da prosperidade está em obedecer aos mandamentos de Deus. A prosperidade não é considerada aqui um assunto econômico no sentido moderno, isto é, explicado somente por teorias e leis econômicas, mas está sob o domínio da vontade divina. Não é o mercado e políticas econômicas do governo que determinam a distribuição de renda, mas sim a vontade divina. Ou melhor, para os que não obedecem aos mandamentos de Deus, o seu sucesso ou fracasso econômico podem depender das leis do mercado e das políticas econômicas dos governos, mas não para os que aceitaram Jesus. Esses estão isentos dessas oscilações e dinâmicas complexas e desconhecidas, eles estão protegidos pelo poder de Deus.

Além de Soares e Hagin, permita-me citar um líder evangélico não tão conhecido para mostrar como essa teologia penetrou em lugares mais distantes. Agenor Farias, que se autoproclama apóstolo, conferencista e líder da Comunidade Vida Abundante na cidade de Araguaiana, Tocantins, escreveu um pequeno texto de divulgação com o título "Prosperidade é benção de Deus". Nesse texto, que faz comentários ao capítulo 8 do livro do Deuteronômio, Farias (2009) conclui dizendo:

Deus tem uma aliança de prosperidade para com todos aqueles que desejam viver dentro dos termos por Ele estabelecidos. O grande desafio do cristão hoje é manter a prosperidade sem se esquecer do Senhor, sem desobedecer à sua Palavra e sem se exaltar. Amém.

A garantia de continuidade da prosperidade de um cristão não reside na sua eficiência econômica, mas sim em obedecer à Palavra de Deus e não se exaltar da sua riqueza. Pois a razão da sua prosperidade não reside fundamentalmente na sua capacidade profissional, mas sim na benção de Deus.

A pergunta que se segue então é: em que consiste a desobediência a Deus? É claro que esta lista não pode ser muito grande. Se assim fosse, não seria possível manter a identidade de evangélico obediente a Deus e viver na certeza da prosperidade.

Na medida em que essa obediência tem a ver com a identidade dos evangélicos abençoados com prosperidade, ela tem que ter relação com a diferenciação entre os evangélicos e os do "mundo", aqueles que não seguem a Palavra de Deus na sua autossuficiência de secularizados. 
E qual é o grande pecado do mundo hoje? Não pode ser o consumismo ou o capitalismo, como critica a teologia da libertação, porque isso seria negar o desejo de participar do consumo e a própria noção de prosperidade como benção. Também não pode ser a injustiça social, porque isso seria criticar o discernimento de Deus na distribuição das bênçãos. Nessa lógica, os pobres que não melhoram sua situação econômica são culpados por não aceitarem Jesus e não seguirem a Palavra de Deus. A mira então se volta ao hedonismo do mundo.

Daniel Bell (1992), um sociólogo norte-americano de linha conservadora, tem uma afirmação sobre o capitalismo que pode nos ajudar a entender essa concentração da crítica dos evangélicos da prosperidade no problema da família e da moral sexual. Ele diz que, no início do desenvolvimento do capitalismo, o impulso econômico sem freio foi controlado pelas restrições puritanas e pela ética protestante, que serviram para limitar a acumulação suntuosa, mas não a acumulação do capital. Com a perda da influência da ética protestante sobre a sociedade burguesa, o sistema capitalista teria perdido a sua ética transcendental e teria restado somente o hedonismo ${ }^{5}$. Ele diz:

A falta de um vínculo transcendental, a sensação de que uma sociedade não brinda algum conjunto de "significados supremos" em sua estrutura de caráter, em seu trabalho e cultura, dão instabilidade a um sistema. O hedonismo, a ideia do prazer como modo de vida, converteu-se na justificação cultural, senão moral, do capitalismo. (p. 33)

Não quero discutir nesse momento a validade da análise de Bell, mas encontramos aqui um exemplo de argumento de um cientista social que vai fortalecer a visão crítica dos evangélicos em relação a modelos de família e de relações afetivo-sexuais não tradicionais. O hedonismo, especialmente ligado, para esse grupo social, ao homossexualismo, aparece aqui como resultado de o mundo moderno ter virado as costas para Deus e sua ética transcendental, isto é, pelo fato de desobedecer aos mandamentos de Deus.

Os temas dos modelos de família e de relações afetivo-sexuais tornaram-se o principal fator de diferenciação dos evangélicos em relação ao mundo em que eles querem

5 Esta ideia de que o sistema capitalista atual perdeu a noção de transcendência, tese também defendida por A. Negri e M. Hardt no livro Império (citado por Sung, Rieger, \& Mniiguez, 2013), não me parece correta, pois sem ela o capitalismo não teria força para expandir o seu domínio sobre o globo, nem justificar sacrifícios de vidas humanas em função de seu objetivo de acumulação ilimitada. entrar e estar dentro, mas em que querem permanecer diferentes.

Mais do que isso, a condição para manterem-se prósperos e "tomar posse" daquilo que Deus reservou de bens materiais para seus "filhos" é obedecer aos mandamentos de Deus. E essa obediência não se restringe à esfera do privado, como pensaria uma pessoa moderna secularizada, mas deve ter impacto também na sociedade. E hoje isso significa fundamentalmente lutar contra o hedonismo do mundo que se voltou contra Deus, lutar contra o homossexualismo e o casamento de pessoas do mesmo sexo.

É o engajamento nessa luta que dá a esse evangélico, que sente no seu cotidiano a instabilidade e os "perigos" da vida econômica no capitalismo competitivo, a certeza de que continuará recebendo as bênçãos de Deus na forma de prosperidade. Ele sabe que Deus não abandonará aqueles que lutam para pregar as leis de Deus a toda sociedade. A agressividade, presente em muitos dos que assumem essa cruzada moral, serve não só para mostrar o fervor religioso, mas também para exorcizar seus medos e inseguranças, projetando nos homossexuais e nos defensores de casamento de pessoas do mesmo sexo toda a culpa por suas próprias inseguranças e frustrações por desejos de consumo ainda não realizados.

Contra uma sociedade que culpabiliza, criminaliza e até demoniza os pobres - "os consumidores falhos" -, as comunidades evangélicas que assumem a teologia da prosperidade afirmam a dignidade humana dos pobres através de uma linguagem religiosa tradicional. Só que, ao não conseguirem ir além dos critérios estabelecidos pela cultura de consumo capitalista, a afirmação dessa dignidade através da promessa de benção/prosperidade traz como outro lado da moeda a luta contra outros modelos de família e de relações afetivo-sexuais que não as tradicionais.

Se a reflexão apresentada aqui tem um mínimo de fundamento, a discussão sobre a posição dessa parcela evangélica da nova classe média brasileira com respeito a família e sexualidade não pode ser restrita a esses campos, mas é preciso situá-la dentro de um contexto social mais amplo. É claro que as diversas formas de diferenciação e constituição de ordens sociais por meio da organização familiar e da classificação sexual são muito mais antigas do que o surgimento do capitalismo. Mas, mesmo sem perder de vista essa longa história, não podemos deixar de perceber como o capitalismo atual determina essas questões de modo mais específico e estabelece novas formas de relação entre economia, família/sexualidade e religião. 


\section{Prosperity, yes! Homosexuality, no!: The new evangelic middle class}

Abstract: There is a remarkable social group within the so called "new middle class" whose interests seek to perpetuate the traditional family and are against homosexual relationships and gay marriage. They are the evangelicals of the prosperity theology. The author of this paper shows that moral militant conservatism, on the one hand, and the adherence to modern and postmodern values of capitalist consumerism culture through prosperity theology, on the other, are not contradictory or necessary out of rhythm in the modernization process of this group. In fact, both of them are the two sides of a single process of the particular affirmation of human dignity of this group.

Keywords: evangelicals, prosperity theology, family, homophobia, religion, modernity.

\section{Prospérité: oui! Homossexualité: non!: la nouvelle classe moyenne évangelique}

Resumé: Parmi les soi-disant «nouvelle classe moyenne», un groupe social se distingue par sa participation sociale et politique dans la défense du modèle traditionnel de la famille et contre le mariage des couples de même sexe et les relations homoaffectives: Il s'agit des évangéliques de la linhe de la théologie de la prospérité. Cet article vise à montrer que le conservatisme moral militant, d'un côté, et l'adhérence aux valeurs de la modernité et post-modernité appartenant à la culture de consommation capitaliste de la théologie de la prospérité d'un autre côté, ne sont pas des aspect contradictoires ou divergents chez ces évangéliques en considérant leur processus de modernisation. En effet, il faut les considérer come les deux faces d'un seul processus de la particularité de l'affirmation que cette groupe fait de la dignité humaine.

Mots clés: évangéliques, théologie de la prosperité, famille, homophobie, religion, modernité.

\section{Prosperidad ¡sí! familia homosexual ¡No!: la nueva clase media evangélica}

Resumen: Existe un grupo social entre la llamada "nueva clase media" que se destaca por su actuación social y política en defensa del modelo tradicional de familia y en contra del matrimonio entre personas del mismo sexo y las relaciones homoafectivas. Estos son los evangélicos de la línea de la teología de la prosperidad. Este artículo pretende mostrar que el conservadurismo moral militante y la adhesión a los valores modernos y posmodernos de la cultura de consumo capitalista, por medio de la teología de la prosperidad, no son aspectos contradictorios o divergentes en el proceso de modernización de este grupo, sino que son dos lados de un único proceso de afirmación de su dignidad humana.

Palabras Clave: evangélicos, teología de la prosperidad, familia, homofobia, religión, modernidad.

\section{Referências}

Asad, T. (1993). Genealogies of religion. Baltimore: Johns Hopkins University Press.

Asad, T. (2003). Formations of the secular: Christianity, Islam, Modernity. Stanford: Stanford University Press.

Assmann, H. (1994). Crítica à lógica da exclusão: ensaios sobre economia e teologia. São Paulo, SP: Paulus.

Assmann, H., \& Hinkelammert, F. (1989). A idolatria do mercado: ensaio sobre economia e teologia. Petrópolis, RJ: Vozes.

Bauman, Z. (1998). O mal-estar da pós-modernidade. Rio de Janeiro, RJ: Jorge Zahar.

Bell, D. (1992). Las contradicciones culturales del capitalismo (4a. ed.). Madri: Alianza Universidad.

Benjamin, W. (2013). O capitalismo como religião. São Paulo, SP: Boitempo. (Trabalho original publicado em 1985)

Farias, A. (2009). Prosperidade é bênção de Deus. Recuperado de http://www.cva12.com.br/index.php?option=com_co ntent\&view=article \&id=10:prosperidade-e-bencao-dedeus\&catid=8:palavra-para-celulas \&Itemid $=7$

Hagin, K. (n.d.). Novos limiares da Fé. Rio de Janeiro, RJ: Graça Editorial.

Josephson, J. A. (2012). The invention of religion in Japan. Chicago: Chicago University. Press.

Masuzawa, T. (2012). The invention of world religions (5a ed.). Chicago: The University of Chicago Press.

Nongbri, B. (2013). Before religion: A history of a modern concept. New Haven: Yale University Press.

Padilha, V. (2006). Shopping Center: a catedral das mercadorias. São Paulo, SP: Boitempo.

Soares, R. R. (2009). Como tomar posse da bênção. Rio de Janeiro, RJ: Graça.

Sung, J. M. (1994). Teologia e economia: repensando a teologia da libertação e utopias. Petrópolis, RJ: Vozes. 
Sung, J. M., Rieger, J., \& Mniguez, N. (2013). Para além do Espírito do Império. São Paulo, SP: Paulus.
Weber, M. (2001). A ciência como vocação. In Ciência e política: duas vocações. São Paulo, SP: Martin Claret. (Trabalho original publicado em 1917)

Recebido: 28/02/2014

Aceito: 30/08/2014 